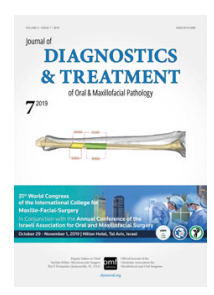

Editorial

\title{
The New England Journal of Medicine: Images in Clinical Medicine: A Role Model Section for DTJournal
}

\author{
Oleksii 0. Tymofieieva \& Rui P. Fernandes ${ }^{b}$
}

Innovation is taking two things that already exist and putting them together in a new way. - Tom E. Freston

American entertainment industry executive

The New England Journal of Medicine (NEJM) from a previous DTJournal's editorial became for us a role model not only as a perfect example how the Editorial Fellowship ${ }^{1}$ should be organized but also motivate us to launch a new Section - Similar to Images in Clinical Medicine ${ }^{2}$ we are starting a Section Pics in Oral \& Maxillofacial Surgery. ${ }^{3}$

Advantages of that Section according to our opinion are: 1) one-page publication, 2) it includes short description (in average, 161 words) of clinical condition, treatment, follow-up (what reduces an author`s time), 3) have one ${ }^{2}$, two ${ }^{4}$, or three ${ }^{5}$ images, and, sometimes, a supplemental video, ${ }^{6} 4$ ) images have no description below as they have in-text descriptions (what a brilliant idea from NEJM's staff), 5) have no references (what increases as well the speed of article's writing, decreases time and cost of lay-out), and 6) can be indexed in PubMed/ MEDLINE similar to research and reports papers, etc.

a Editor in Chief, DTJournal; Kyiv, Ukraine.

E-mail: tymofeev@gmail.com (Oleksii Tymofieiev)

${ }^{\mathrm{b}}$ Deputy Editor in Chief, DTJournal; Jacksonville, FL, USA.

E-mail: rui.fernandes@jax.ufl.edu (Rui Fernandes)

https://dx.doi.org/10.23999/j.dtomp.2019.7.1

(C) 2019 OMF Publishing, LLC. This is an open access article under the CC BY license (http://creativecommons.org/licenses/by-nc/4.0/).
In conclusion, we are thrilled to introduce you a founding section`s editor Dr. Camilo Mosquera from Bogotá. Who's made a strong impact in DTJournal with his Columbian colleagues presenting a delightful article dedicated to paragonimiasis. ${ }^{7}$

\section{REFERENCES}

1. Fesenko IP. Important part of journal's growth and success: editorial fellowship. J Diag Treat Oral Maxillofac Pathol 2019;3:173. https://dx.doi. org/10.23999/j.dtomp.2019.6.3.

2. Brucoli M, Benech A. Spindle-cell sarcoma of the tongue. $N$ Engl J Med 2019;380:e10. https://dx.doi. org/10.1056/NEJMicm1810192.

3. Demidov VH, Ripolovska OV. How multiple the submandibular gland sialoliths can be? J Diag Treat Oral Maxillofac Pathol 2019;3:174-5. https://dx.doi. org/10.23999/j.dtomp.2019.7.2.

4. Katz MG, Russell KW. Injury from e-cigarette explosion. N Engl J Med 2019;380:2460. https:// dx.doi.org/10.1056/NEJMicm1813769.

5. Pata F, Di Saverio S. Pneumatosis cystoides intestinalis with pneumoperitoneum. N Engl J Med 2019;380:e17. https://dx.doi.org/10.1056/NEJMicm1808960.

6. Kang WH, Jee SC. Enterobius vermicularis (pinworm) infection. N Engl J Med 2019;381:e1. https://dx.doi. org/10.1056/NEJMicm 1811156.

7. Mosquera C, Rincón L, Estrada C, Franco J. Paragonimiasis with oral cavity colonization: first case report. J Diag Treat Oral Maxillofac Pathol 2019;3:17682. https://dx.doi.org/10.23999/j.dtomp.2019.7.2. 